\title{
Training future primary school teachers for the formation of students' skills to cooperate in a team
}

\author{
Oleksandra Yankovych ${ }^{1,2, *}$, Iryna Kuzma ${ }^{3, * *}$, Vitaliia Prymakova ${ }^{4, * * *}$,Zinovii Onyshkiv ${ }^{1, * * * *}$, and Hanna Chaikovska ${ }^{1, \dagger}$ \\ ${ }^{1}$ Ternopil Volodymyr Hnatyuk National Pedagogical University, 2 Maksyma Kryvonosa Str., Ternopil, 46027, Ukraine \\ ${ }^{2}$ Kujawy and Pomorze University in Bydgoshch, 55-57, Toruńska Str., Bydgoshch, 85-023, Poland \\ ${ }^{3}$ Ternopil Regional Munisipal Institute of Postgraduate Pedagogical Education, 1 Hromnytskoho Str, Ternopil, 46027, Ukraine \\ ${ }^{4}$ Municipal Higher Educational Institution "Kherson Academy of Continuing Education” of Kherson Regional Council, 41 Pokrysheva \\ Str., Kherson, 73040, Ukraine
}

\begin{abstract}
The model of training future primary school teachers for the formation of students' skills to cooperate in a team is developed and experimentally tested in the article. There are the following components of this model: goals, methodological approaches, content (the structure of the ability to work in a team is considered), the main stages, forms, methods, means, diagnostic tools and the result of the studied training. The skills to cooperate in a team are explored in the article as a complex formation and as one of the soft skills. At higher education institutions, the future teachers training for the formation at primary school students' skills to collaborate in a team takes place mainly during the implementation of interactive, game and project methods. However, this training needs to be improved. The developed experimental model implies systematic work on the basis of Pedagogy of the Heart and Pedagogy of Success, as a methodological basis of the researched process; equivalence of tendencies of using group work to improve learning outcomes and group work as a means of formation of students' ability to interact. Experimental verification proved the effectiveness of the designed model: the number of representatives at a high level of readiness to develop primary schoolchildren' ability to work in a team significantly increased and there were no low-level representatives.
\end{abstract}

\section{Introduction}

We are at the stage of development of human civilization, when effective social transformations, development and implementation of startups, implementation of inventions in science, technology, medicine, information technology require the collective efforts of firms, enterprises, campaigns, research institutions. Increasingly more often we talk about teamwork and the ability to collaborate in a team, which should be formed as early as possible in children and youth. This skill is one of today's relevant soft skills.

The ability to interact is one of the key competencies of students in primary school, and therefore, the relevance of training future teachers at higher education institutions to form such competence in students is growing.

Due to the need to solve this problem, a number of unresolved issues arise: are we not in too much in a hurry when we develop the ability to teamwork in primary school students; are graduates of pedagogical specialties of higher education institutions ready for this process; what is the level of such readiness, what does it mean - to be able to work in a team?

\footnotetext{
*e-mail: yankov@tnpu.edu.ua

**e-mail: iryna.ihorivna.kuzma@gmail.com

***e-mail: pran703@gmail.com

****e-mail: z.onyshkiv@gmail.com

†e-mail: chaicov@elr.tnpu.edu.ua
}

Usually, both teachers and students-future teachers are convinced in the need of primary school students to be prepared to interact with others, because the level of formation of this competence defines later their abilities of selfrealization and success.

At the same time, the analysis of biographies of famous people gives grounds for a more thorough study of this problem. Elon Musk was a victim of bullying at school, there were problems with peer interaction, but this did not prevent him from the establishment of a number of world-famous campaigns and tremendous success. The victims of bullying during the school years were worldfamous people - motivational coach Nick Vujicic, film actor Christian Bale, pop star singers Taylor Swift, Miley Cyrus and others.

After all, we have examples when even great teachers felt oppressed by peers as children and were not great authorities, in particular the world-famous writer and teacher Anton Makarenko was a frail sick child, but later he became the head of a colony and then a commune for homeless children, being able to group the pedagogic and children's teams. These and other facts encourage the scientific research to address the issue of training future teachers to develop the ability of younger students to interact, cooperate in a team. We assume that the task of the school may be to give children knowledge, develop individual talents, personal qualities (diligence, decency, humanity, 
etc.) as a basis for their future achievements, and to train teachers for this mission. The scientific interest is focused on the resolution of problem as far as skills to cooperate in a team contributes to students' learning in conditions of pandemic.

\section{Literature review}

The ability of students to interact with each other and with other people, teams is associated in pedagogical theory and practice primarily with the implementation of interactive methods (group work, brainstorming, aquarium, etc.), project work and the formation of the class team. Interactive methods, their role in the development of collectivist qualities are the subject of research by A. DeJuanas [1], V. Esarte-Sarries [2], P. Fernández-Lozano [1], M. González-Ballesteros [1], L. Hargreaves [2], B. Kubicek [3], J. Moyles [2], U. Ordon [4], O. Pometun [5], M. Roger [2], M. Szczotka 6, K. Szewczuk [6], E. Wójcik [7] etc. The use of interactive and other methods of cooperation in a team in higher education institutions was described by M. Dgebuadze [8], E. Faciu [9], M. Giorgdze [8], I. Lazar [9] and others.

The formation of the ability to interact, learning in interactive groups is considered in terms of improving the learning outcomes, rather than acquiring the ability of multilateral communication. In particular, U. Ordon states that the use of interactive methods increases the effectiveness of learning, makes it more attractive, and facilitates the formation of skills. In combination with play, these methods increase the motivation to learn, which is important in the conditions of young age when a child starts learning [4].

Interdisciplinary learning, multifaceted communication during learning are considered not only in terms of strengthening knowledge, but also as links with social changes: it is considered as a means of developing social skills.

Collaboration and cross-discipline teaching and learning, for example through projects, team-teaching and learner-led activities, improves engagement and learning outcomes in a range of competencies. Cross-discipline learning also allows for strengthening the connectivity between the different subjects in the curriculum, as well as establishing a firm link between what is being taught and societal change and relevance [10].

Training future teachers for formation of soft skills (teamwork is a component of these skills) is considered in the works of A. Abdula [11], H. Baluta [11], A. Bohinska [12], D. Cretu [13], M. Hashimah [14, 15], D. Kassim [11], N. Kozachenko [11], R. Kravets [16], I. Mintii [12], H. Nor [14], O. Pehota [16], L. Romanyshyna [16], I. Shorobura [16], K. Tang [14, 15, 17], T. Vakaliuk [12], I. Varava [12], V. Vykhrushch [16], etc. In particular, K. Tang, M. Hashimah, H. Nor offer to make changes in the content of future teachers training and to introduce an integrated module in professional training. "Since soft skills are important prerequisite in shaping an individual's personality, therefore it is recommended that teacher edu- cators should utilize the integrated soft skills training module during teaching professional training" [14].

The analysis of the pedagogical sources allows to reveal interesting ways, methods which can be used in the course of training future teachers for the formation of students' ability to collaborate in a team. L. Budevici Puiu proves the necessity of change and development of the higher education institution in the age of globalization [18]. L. S. Tudor considers initial training of teachers for preschool and primary education from the perspective of modern educational paradigms [19]. K. Binytska, V. Chaika, O. Pysarchuk, I. Yashchuk et al. stressed the need to introduce Pedagogy of the Heart, despite E. Piecuch's attempts to consider it utopian [20].

P. Fernández-Lozano, M. González-Ballesteros, A. De-Juanas emphasize that cooperation is not just a way of learning, but a culture that should be integrated into interaction with others: "Cooperation is more than just a way of learning; it is a culture which should be integrated into how we interact with those around us" [1]; they offer to use interdisciplinary cooperation between teachers of different disciplines, encouraging them to create common teams; learning new technologies: "We consider that collaboration between teachers of different disciplines and with other professionals is desirable, to pool ideas on interesting projects and tasks involving interdependence and intended to develop basic competencies for the future professional careers of the students in different degree courses" [1].

"We consider that university teaching staff must be trained in the use of new technologies and that teaching centers should be equipped with the resources needed to enable cooperative work inside and outside the classroom" [1].

Teamwork of teachers is the subject of research by F. Dochy, E. Kyndt, E. Raes, K. Vangrieken [21, 22] and others. However, the wholesome issue of training future primary school teachers for the formation of students' ability to work in a team still is not studied thoroughly. There is a need to clarify the structure of the ability to cooperate in a team and substantiate the new ways of training future teachers for its formation in students.

Insufficient research of the problem and the necessity of a comprehensive solution to these issues determined the aim of the study: to develop and experimentally test the model of training future primary school teachers to the formation of students' ability to cooperate in a team.

\section{Methodology}

In order to solve the problem of training future teachers for the formation of primary school students' ability to work in a team, the retrospective analysis methods were used to search in the historical and pedagogical literature for promising ways of formation of these skills. There were studied the sources, which cover the ways of interaction of primary school students during the period of the second half of the XX till the early XXI century. These are primarily periodicals that describe the practice of the effective interaction between children in primary school. 
Another important method is the experiment - the constative and formative one, which was conducted among graduate students of Mukachevo State University, Ivan Franko Drohobych State Pedagogical University, Volodymyr Hnatiuk Ternopil National Pedagogical University during 2019-2020. There were 202 students participating in the experiment. The control groups included 104 students; the experimental ones - 98 students. About 74\% of students participating in the experimental groups already had experience as teachers in primary schools. Only one participant in the experiment was male; others - females.

In the process of the experimental work, the modeling methods were used in order to develop a model of training future teachers to form in students of primary school age the ability to collaborate in a team; questionnaires, surveys, testing, method of expert evaluation, interviews with teachers-specialists in primary education - to develop diagnostic tools and experimental verification of the effectiveness of the studied model.

The expert assessment during the experiment (indicators of motivational and valuable, resultative-analytical criteria) was carried out by the Deputy Dean of the Faculty of Pedagogy and Psychology; Head of the Department of Pedagogy and Methods of Primary and Preschool Education of Volodymyr Hnatiuk Ternopil National Pedagogical University and a Master course student who performed a Master's thesis on retrospective analysis of cooperation in a team of primary school students. The expert assessment was done by means of analysis of the results of realization of methods of "incomplete sentences", interviews and questionnaires. During the experiment students-future teachers answered the following questions:

1. What do you understand by the ability to cooperate in a team?

2. Is it worth to form the ability to cooperate in a team in primary school children?

3. How, in your opinion, it is possible to form students' ability to cooperate in a team?

4. Do you use the methods for diagnostic the formation of personal qualities, which are important for the cooperation in a team? If yes, which ones?

5. Do you feel yourself trained enough to form the ability of younger students to work in a team?

6. How do you think, teachers are able to work in a team?

\section{Results}

\subsection{The structure of the ability to work in a team}

The ability to work in a team involves mastering a set of different methods and techniques.

We asked the postgraduate students future teachers to choose the definition of the notion of teamwork. Students were offered the following answers as options: a) communicate effectively,

b) not too conflict,

c) perform a collective task with the whole group, not individual students, and

d) your own answer.

The survey involved 96 people - both full time and correspondence department postgraduate students of Volodymyr Hnatiuk Ternopil National Pedagogical University; $98.96 \%$ of them were females; 1 person $(1.04 \%)$ was a male. All the proposed options were chosen by 88 people $(91.7 \%)$, indicating that this was the achievement of the goal by all participants, not individual members. The option to communicate effectively and not to conflict was chosen by 8 respondents (8.3\%). In addition, 4 (4.2\%) respondents wrote that the ability to work in a team was to help each other. A small number of students-future teachers who expressed a need of primary school children' support, caused the necessity to introduce the ideas of Pedagogy of the Heart.

To the question of how, in your opinion, it is possible to form students' ability to cooperate in a team, it was possible to choose the following answers: to teach in interactive groups; to involve students in the implementation of collective projects (educational and upbringing); to form harmonious relationships between students in the classroom; to bring up humanism, warm relations; to teach in communication to use strategies of cooperation, compromises; and to offer your own answer.

Only 24 students $(33 \%)$ chose the option of "bringing up humanism, warm relations". Most often, students chose the option of "teaching in interactive groups; involving students in the implementation of collective projects (educational and upbringing)" -60 respondents (62.5\%); besides, only one option - "involving students in the implementation of collective projects (educational and upbringing)" was chosen by 8 students (8.3\%), "teaching in interactive groups" - by 4 (4.2\%).

We also used the method of "incomplete sentences" and suggested to finish the following sentence: "The ability to work in a team is...". The most interesting are the following answers, which demonstrate the depth of understanding this idea: "The ability to work in a team is the ability to perform a task set before a group of people through cooperation and effective communication"; "This is an activity that consists of actions aimed at achieving the goal. It requires leadership skills, such as the ability to influence people and be persuasive, to listen to the point of view of colleagues, to respect their opinion. It assumes the need to control one's emotions in order to cope better with most stressful situations. Communication skills play an important role in working with a team, the ability to understand everything that happens between people and inside of people, to understand the meaning of their actions, experiences, thoughts, aspirations, it's all important".

We asked students whether primary school children should develop the ability to cooperate in a team. Majority of students - 94 respondents $(97,9 \%)$ gave an affirmative 
answer; $2(2.1 \%)$ students answered "no, because there is no specially developed methodology for the formation of this skill".

When asked if they feel ready to form the ability of younger students to work in a team, 8 respondents $(8.2 \%)$ wrote "no", $4(4.1 \%)$ respondents wrote that they lacked a focus on the formation of such a skill, as well as a special methodology that would aim at the formation of such a skill. Students, determining the ability to work in a team, primarily focused on communication, the ability to resolve conflicts, involving all team members in the work, rather than active and competent individuals. Less often they wrote about managing emotions and helping each other.

Unfortunately, only 4 students $(4.2 \%)$ of the participants in the experiment answered that the ability to work in a team consists of support, help each other, this is what we call the ability to interact on the basis of Pedagogy of the Heart (empathy, perception, and choice of this strategy of behavior).

None of the participants in the experiment wrote that the ability to work in a team is the ability to obtain the necessary information, improve knowledge, competence in the field in which the team works; these are reflective skills - the abilities to analyze the achievements and shortcomings of the work and predict work strategies. They did not write about self-improvement of personal qualities; while it requires personal qualities that are usually the decisive criterion by which we would or would not involve a person in our team.

Of course, this does not mean that such skills of intellectual, reflective or self-improvement are denied by students as necessary for teamwork. When students were asked about this, they agreed on the necessity of this skill. But they do not name the mentioned skills, only by teacher's initiative.

After studying the opinions of student-teachers and conducting our own research, we determined the structure of the skill to cooperate in a team (figure 1).

Organizational skills - to set goals, develop plans of their implementation, time management.

Managerial skills - to distribute responsibilities, manage and obey team requirements.

Intellectual and information skills - to continue education, to obtain information.

Communicative skills - to communicate productively; prevent conflicts or resolve constructive conflicts.

Emotional-volitional skills - to control emotions, their inner state, to demonstrate volitional qualities.

Humanistic-oriented skills - the abilities to support and provide practical assistance, to penetrate into the essence of another person, to operate on a "heart to heart" principle.

Reflexive skills - the abilities of the in-depth analysis of one's strengths, weaknesses, activities of each team member, intermediate results. Ability to draw conclusions and correct mistakes.

We asked whether the formation of these skills would be the only criterion for selecting a team of followers to perform a pedagogical assignment. At the same time, we found out that an important criterion was presented with personal traits - honesty, sincerity, decency, humanity. Certain skills can be acquired if you are the respected person. We took this into account when determining the indicators by which we measured the level of readiness of future teachers to develop the ability of primary school children to interact in a team. Unfortunately, measuring the level of formation of these qualities is not paid due attention, as well as to the preparation of students for such diagnostic procedures. We set a task to eliminate this shortcoming in our study.

\subsection{Diagnosis of readiness of future teachers to form teamwork skills in junior schoolchildren}

Determining diagnostic tools for future teachers' readiness to develop teamwork skills in junior school children is a process that takes into account a number of factors, especially the structure of teamwork skills, the results of our research, scientists' approaches to diagnosing future teachers' readiness for certain professional activities (for example, diagnostic, innovative, to the formation of the class team, etc.) [20]. Taking them into consideration, we identified the criteria, indicators and levels of readiness of future teachers to develop students' ability to interact in a team, methods for measuring each of these indicators, showing them in table 1.

To measure the level of formation of each indicator, we determined the appropriate method, evaluating from 1 to 20 points. We assessed the level of formation of five indicators that characterize the readiness of future teachers to develop pupils' ability to cooperate in a team. The maximum amount of points a student could be evaluated was 100 points. It corresponds to the scale according to which students' educational outcomes (credits and exams) are assessed during the university study.

High-level representatives could score from 90 to 100 points; sufficient - from 75 to 89 points; satisfactory from 60 to 74 points; low - from 1 to 59 points. This corresponds to the scale of student assessment during the examination sessions.

\subsection{Forms, methods, technologies of training future teachers for formation of skills of team work at primary school students}

Training future teachers for the formation of younger schoolchildren's ability to collaborate in a team takes place in the course of study of all educational disciplines. The wide-spread methods in the educational process at university are interactive ones, including "group work", "take position", "aquarium", "rotating threes", "merrygo-round", "thinking hats", "brainstorming" and others. Game and project methods are also quite popular. These methods have a long history of development. They were applied for the first time centuries ago, or much earlier, in particular, the game method.

At the same time, a retrospective analysis of primary education in Ukraine made it possible to identify promising methods that are worth reviving in the educational process: the implementation of collective creative work; 


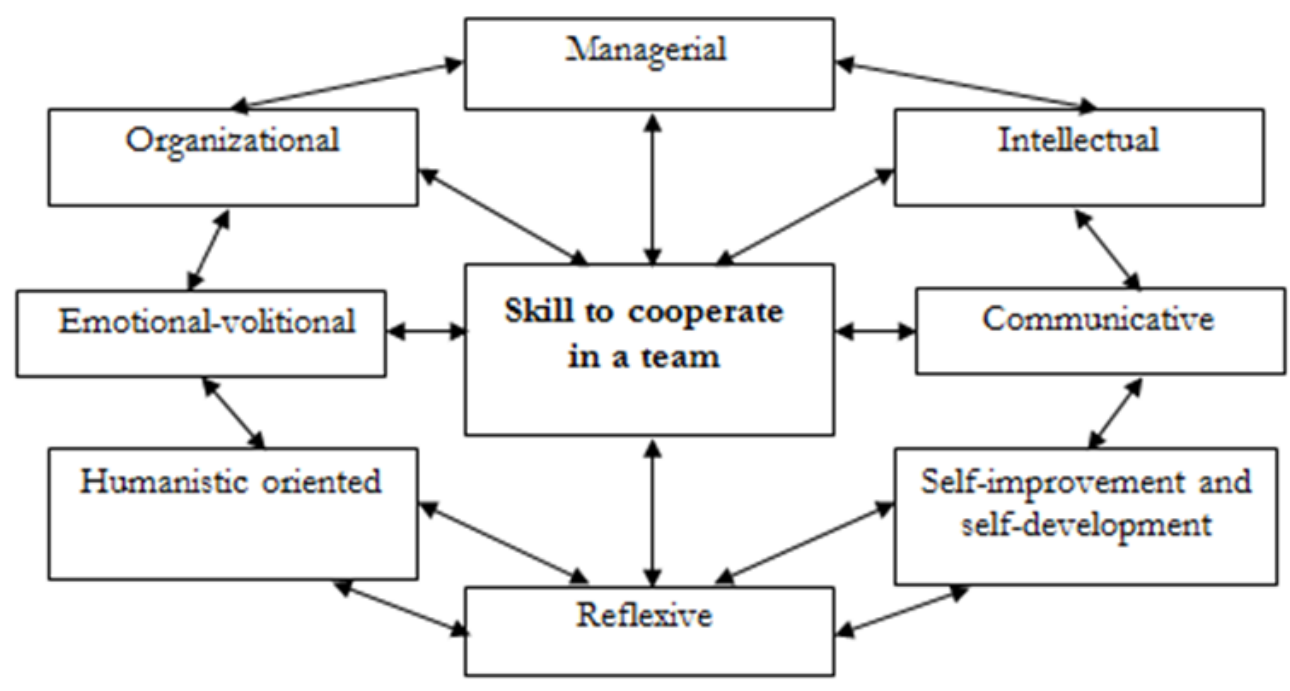

Figure 1. The structure of the skill to cooperate in a team

Table 1. Criteria, indicators and methods for determining the indicators of readiness of future primary school teachers to form students' ability to work in a team, (source: own work)

\begin{tabular}{|c|c|c|}
\hline Readiness criteria & Indicators & Method \\
\hline $\begin{array}{l}\text { Motivational and } \\
\text { valuable }\end{array}$ & $\begin{array}{l}\text { Level of awareness of the importance of the studied } \\
\text { skills and the development of personal qualities for } \\
\text { teamwork. }\end{array}$ & Survey, questionnaire, interview. \\
\hline $\begin{array}{l}\text { Personal- } \\
\text { diagnostic }\end{array}$ & $\begin{array}{l}\text { The level of formation of diagnostic skills to measure } \\
\text { the development of personal qualities necessary for the } \\
\text { interaction of students: honesty, decency, sincerity, hu- } \\
\text { manity, communicative skills. }\end{array}$ & Survey, questionnaire, interview. \\
\hline Cognitive & $\begin{array}{l}\text { Knowledge of forms, methods of teamwork; technolo- } \\
\text { gies, which are used to form a coordinated teamwork. }\end{array}$ & Tests. \\
\hline Procedural & Level of realization of forms, methods of work. & $\begin{array}{l}\text { Estimation of performance of edu- } \\
\text { cational affairs during pedagogical } \\
\text { practice; interview. }\end{array}$ \\
\hline $\begin{array}{l}\text { Resultative- } \\
\text { analytical }\end{array}$ & $\begin{array}{l}\text { Assessment and self-assessment of skills formation, } \\
\text { identification of prospects. }\end{array}$ & $\begin{array}{l}\text { The method of incomplete sen- } \\
\text { tences. }\end{array}$ \\
\hline
\end{tabular}

evaluation of the contribution into teamwork with the help of magic rulers; the student's work at the blackboard in the special support team he/she had chosen; the use of a mat of reconciliation, on which children communicate in a friendly and constructive manner during reconciliation (for example, "Let's work it out"); games "Kvach, give a hand", "Two frosts", which imply assistance to a classmate in a difficult moment, conducting classes like "Emblem of professions" (students in the "workshops" develop an emblem of the profession they represent), etc. The method of evaluation with the help of magic rulers in our study was adapted to the research topic. Students evaluated their contribution to the work of the team with the letters "A" activity, "D" - diligence; "C" - creativity, etc. according to a 12-point scale (this is the rating scale used in schools of Ukraine).

Training future teachers for the formation of the ability of primary school students to interact in a team involves the use of not only traditional methods but also innovative ones. In addition, it is necessary to take into account not only the positive potential of traditional methods, but also their negative aspects. Group work can take place with the activity of one or two students, and the others will only use the overall result; teamwork is noisy, and it requires a lot of teacher's skills to organize it.

A new approach is emerged to the training future teachers in the context of developing the ability at primary school children to interact in a team in changing priorities: the equivalence of trends in group work to improve learning outcomes and group learning as a means of developing students' ability to interact. We propose to emphasize the formation of teamwork skills for life self-realization.

The innovations of our experimental work at the university are its systematicity and complexity: focus on national and foreign both historical-pedagogical and modern achievements, ideas of Pedagogy of Heart and Pedagogy of Success; formation of students' motivation to use teamwork and independent design of non-standard methods and techniques relevant to modern teamwork of schoolchildren and their reflection in the e-book; prepar- 
ing students for diagnostic activities in the context of measuring primary school children' personal qualities that are important for teamwork; study of technologies, interesting methods, techniques of pedagogical theory and practice and their application during pedagogical activity; training for the formation of schoolchildren' reflective skills. Since students need a special method (system) of formation of primary school children' ability to interact in a team, we have developed a model of this process.

The model of our proposed system of training for the formation of primary school students' skills to interact in a team is shown in figure 2 .

\subsection{Analysis of the results of the experiment}

The experimental work was carried out in Volodymyr Hnatiuk Ternopil National Pedagogical University, Ivan Franko Drohobych State Pedagogical University, Mukachevo State University. In control groups (104 students) training was conducted in a tradition way. In the experimental groups (98 people) - according to the developed model.

The experiment, lasting 1 academic year, began in September 2019 and was completed in May 2019.

In September 2019, we conducted diagnostic procedures in experimental groups ( 3 groups; full-time and correspondence department). It turned out that $11(11.2 \%)$ postgraduate students are at a high level; $47(47.9 \%)$ - at a sufficient one; $33(32.7 \%)$ - at a satisfactory one; $8(8.2 \%)$ - at a low level. An experimental model was implemented in these groups.

At the first stage - motivational and goal setting - motivation was created to form the ability to cooperate in a team, the advantages it gives, the achievement of modern teams, including schoolchildren and universities. It was noted that this skill was determined by The Council of the European Union in a Recommendation on key competences for lifelong learning [23].

At the second - diagnostic-informative stage - approaches to the interpretation of the notion of teamwork, the requirements of standard programs for primary school in terms of the ability to interact were comprehensively studied; as well as the forms, methods, tools and technologies suitable for use at the primary school in the context of teamwork. We didn't only teach students to use interactive, project, game methods, etc., but also prepared them to use these methods in schools as a means of developing teamwork skills [24]. Emphasis was made on diagnostic procedures: tests, including humorous ones: Who am I? What am I?

Interesting tasks in the context of teamwork, in our opinion, are: games "Captain" (ship crews are created to study recreational facilities; there was not only a distribution of roles, but also a cost estimate was prepared within the given limits); "Delicacies in support of a friend" (presupposed role distribution, choice of the delicacies to be prepared, team implementation and money estimation to be raised in order to treat a friend), "Green Tourism" (implied creation of several teams to provide recreational services; the winners were determined judging by quality- price correlation; however, each team won in different nominations), "Sherlock Holmes" (one of teams produced a text with deliberately made mistakes, the other team found them and corrected) and others. The students discussed experimental researches over the past 50 years devoted to the formation at pupils' ability to interact, but whose ideas still remain relevant. The researchers noted that children with a selfish orientation, when acting as a leader, behave in an organized, intelligent and restrained manner; if they were offered to obey - their style of behavior changed dramatically, escalating a conflict. The students interested in the selected types of children with features of local collectivism (humane only within their group) and group selfishness (in their group - disorganized, and in the transition to "foreign crew" the situation got even worse), as well as the proposed methods of influencing on children. The researchers recommended to apply methods of persuasion to disorganized students, as well as to search for their interests and provide assistance in the development and realization of the child's capacities [25].

Significant attention in the study was paid to training students for the realization of humanistic potential in the team, mutual assistance, giving support of each child, as well as the impact on timid students who show signs of "learned helplessness", known since the 1960's, and described in the works of C. Peterson, S. Maier, M. Seligman [26].

We also implemented the ideas of students that were indicated at the stage of the questionnaire. Those with an interesting experience of schoolchildren teamwork (both positive and negative), shared it at the classes and online.

We analyzed the examples of famous people who were bullied as children and who did not make friends with peers. We came to the conclusion that such children need help. After all, not everyone has got enough courage to face the circumstances. Sometimes children commit suicide because of bullying. Therefore, while forming the ability to interact with others, it is necessary to emphasize the need to follow the law and respond correctly to all cases of its violation.

In the questionnaires at the beginning of the experiment, students were asked the question: "Do you consider teachers to be ready for teamwork?". Only 20 (20.8\%) out of 96 students gave an affirmative answer. Others said teachers were ready rather than they were not.

This response, as well as the results of the research, prompted the use of teamwork of both teachers and students, which was implied at the third - the performative stage of the developed model. Teams of teachers and students were formed as a result of scientific research, presentation of the faculty to applicants, when they made choice of their future profession; during faculty events; competitions of social projects. We started the experiment when there was no threat of the Covid-19 pandemic, and finished it during the pandemic. Some tasks (discussion of virtual classes in primary school, implementation of diagnostic procedures, etc.) had to be performed in a team. Based on interviews with students, it was concluded that a number of educational tasks, such as project implemen- 


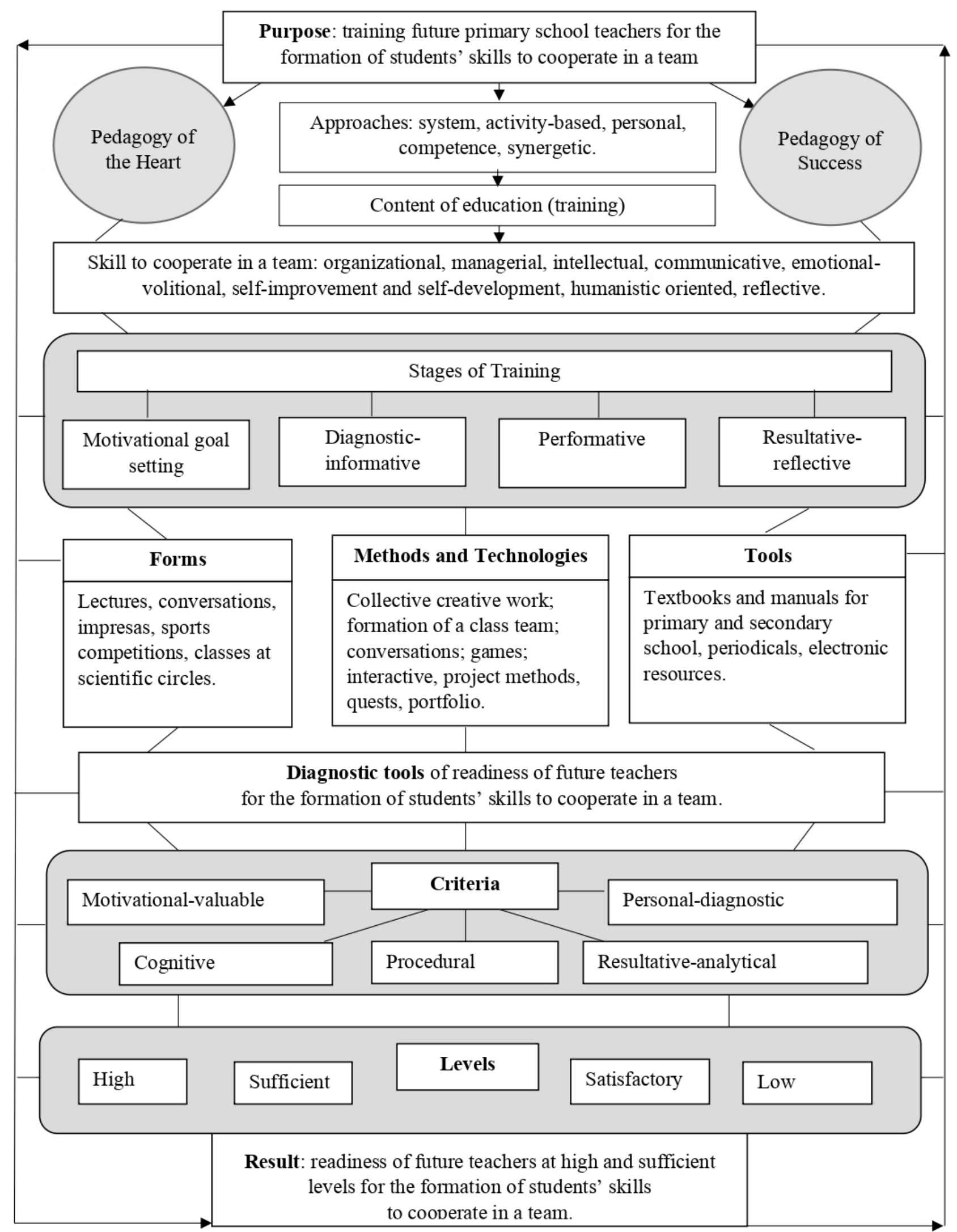

Figure 2. Model of training future primary school teachers for the formation of students' skills to cooperate in a team 
Table 2. Distribution of students of experimental groups by levels of readiness to the formation of students' ability to work in a team (formative stage of the experiment)

\begin{tabular}{lll}
\hline Levels & \multicolumn{2}{c}{ Distribution of students by levels } \\
& $\begin{array}{l}\text { Before the experi- } \\
\text { ment }\end{array}$ & $\begin{array}{l}\text { After the experi- } \\
\text { ment }\end{array}$ \\
\hline High & 11 persons $(11,2 \%)$ & 33 persons $(33,7 \%)$ \\
Sufficient & 47 persons $(47,9 \%)$ & 46 persons $(46,9 \%)$ \\
Satisfactory & 32 persons $(32,7 \%)$ & 19 persons $(19,4 \%)$ \\
Low & 8 persons $(8,2 \%)$ & - \\
\hline
\end{tabular}

Table 3. Distribution of students of control groups by levels of readiness to the formation of students' ability to work in a team (formative stage of the experiment)

\begin{tabular}{lll}
\hline Levels & \multicolumn{2}{c}{ Distribution of students by levels } \\
& $\begin{array}{l}\text { Before the experi- } \\
\text { ment }\end{array}$ & $\begin{array}{l}\text { After the experi- } \\
\text { ment }\end{array}$ \\
\hline High & 12 persons $(11,5 \%)$ & 14 persons $(13,5 \%)$ \\
Sufficient & 48 persons $(46,2 \%)$ & 51 persons $(49,0 \%)$ \\
Satisfactory & 35 persons $(33,7 \%)$ & 31 persons $(29,8 \%)$ \\
Low & 9 persons $(8,6 \%)$ & 8 persons $(7,7 \%)$ \\
\hline
\end{tabular}

tation, problem solving, portfolio creation, e-books, manuals, teamwork, work with a partner, are a temporary alternative in conditions of pandemic to school lessons and classes at the university. Group forms of work, work in pairs, in students' opinion, contribute to the development of motivation to learn, the development of social skills, especially mutual assistance and support in the conditions of pandemic stronger than in the context of usual learning. However, this is no more than a temporary alternative, as far as the real learning is more effective than the virtual one.

At the last stages of the experiment (resultativereflexive) the students were asked to complete the sentences.

I'm ready to develop teamwork skills in elementary school because... However, I still lack the skill of...

I feel that I am not quite ready to develop skills in students.... (After the experiment: $33.7 \%$ of postgraduate students were at a high level; $46.9 \%$ - at a sufficient level; $19.4 \%$ - at a satisfactory level; $0 \%$ - at a low level).

The results of the experimental work are presented in tables 2 and 3 .

The results of students of control groups (104 persons) almost did not change.

The results of future primary school teachers readiness to the formation of students' ability to work in a team of control and experimental groups confirm the effectiveness of the developed methodology.

\section{Discussion}

The results of the experiment testified to the effectiveness of the developed experimental model. But, in our opinion, a change in priorities in the interpretation of the ability to cooperate in a team is the main achievement.
Before the experiment, students-future teachers paid more attention to the ability to distribute responsibilities, perform a collective task with the whole group, and after the experiment - to the ability to support each other, provide practical support, say a sincere word of praise. So, cooperation on the ideas of Pedagogy of the Heart became the main thing. Before the experiment, only 4 students $(4.2 \%)$ of the participants in the experiment answered that the ability to work in a team is support, help each other. After the experiment, all members of the experimental group mentioned first of all help and sincere compliments as manifestations of the ability to cooperate. The participants of the experiment learned more about the ideas of Pedagogy of Success and Pedagogy of the Heart and their significance in the educational process of educational institutions. At the same time (32 students of the experimental group $-32.7 \%$ ) noted that in the conditions of competition there is a negative tendency to show qualities that contradict the ideas of Pedagogy of Heart (envy, deception, manipulation, etc.).

We provided the results of the experiment for acquaintance and use to students and lecturers of Vasyl Stefanyk Precarpathian National University, Yuriy Fedkovych Chernivtsi National University. They admit that the results were interesting to them, somewhat unexpected, but worth studying and implementing. There were identified discussion questions about helping a person in a team that is likely to become a competitor in the future; feelings of inferiority among people with a higher level of competence.

Considering the problem of training future teachers for the formation of primary school students' ability to cooperate in a team, we found out that the following tasks require further comprehensive research: genesis of this problem; the formation of soft skills in primary school students; overcoming obstacles as to the formation of students' ability to cooperate in a team.

\section{Conclusion}

The ability to work in a team for primary school students is a complex formation that contributes to the formation of key competencies for life, and requires special training for future teachers. A person who knows how to work in a team has a number of skills: organizational, managerial, intellectual, communicative, emotional and volitional, self-improvement and self-development of personal qualities, humanistic, reflexive. According to the research, a significant proportion of future teachers (approximately $40 \%$ ) is not sufficiently trained for the formation of this skill in primary schoolchildren and they are at a satisfactory or low level of readiness for such activities. Thus, there is a need for systematic work, which is reflected in the experimental model: the introduction of the ideas of Pedagogy of the Heart and Pedagogy of Success as a methodological basis for the process; the application of the potential of all educational disciplines; preparation for wider use of diagnostic procedures; search and implementation of promising non-standard methods and techniques of teamwork of school children; mastering modern technologies and methods of teamwork; creation of 
teams of teachers and students for scientific searches, career guidance work, events and festive theatrical performances. According to the research results, as a result of the introduction of the experimental model, there is not a single student who is at a low level of readiness to develop primary schoolchildren' ability to work in a team. The number of high-level representatives has significantly increased (tripled): from 11 (11.2\%) to 33 (33.7\%), which testifies to the effectiveness of experimental work.

\section{References}

[1] P. Fernández-Lozano, M. González-Ballesteros, A. De-Juanas, Electronic Journal of Research in Educational Psychology 10, 171-194 (2012)

[2] J. Moyles, L. Hargreaves, M. Roger, V. EsarteSarries, Interactive teaching in the primary school (Open University Press, 2003)

[3] B. Kubiczek, Active methods. How to teach students to study? (NOWIK Sp.j, Opole, 2009)

[4] U. Ordon, Elementary Education in Theory \& Practice 37, 129-143 (2015)

[5] O. Pometun, Encyclopedia of interactive learning (A.S.K., Kyiv, 2007)

[6] M. Szczotka, K. Szewczuk, Elementary Education in Theory \& Practice 14, 105-120 (2019)

[7] E. Wójcik, Activating methods in the pedagogy of a team (Publishing house „Rubikon”, Kraków, 2008)

[8] M. Giorgdze, M. Dgebuadze, International e-Journal of Advances in Education 3, 544-548 (2017)

[9] I. Lazar, E. Faciu, Revista Romaneasca pentru Educatie Multidimensionala 11, 113 (2019)

[10] European Commision, Supporting key competence development: learning approaches and environments in school education (2019), https://tinyurl. com/8msy4uup

[11] A. Abdula, H. Baluta, N. Kozachenko, D. Kassim, CEUR Workshop Proceedings 2643, 306 (2020)

[12] I.P. Varava, A.P. Bohinska, T.A. Vakaliuk, I.S. Mintii, Journal of Physics: Conference Series (2021, in press)
[13] D. Cretu, Fostering 21st century skills for future teachers, in The European Proceedings of Social $\mathcal{F}$ Behavioural Sciences (2017), p. 672-681, https://www . europeanproceedings . com/ files/data/article/54/1749/article_54_ 1749_pdf_100.pdf

[14] K. Tang, M. Hashimah, H. Nor, Procedia - Social and Behavioral Sciences 186, 835-840 (2015)

[15] K. Tang, H. Nor, M. Hashimah, Procedia - Social and Behavioral Sciences 177, 284-288 (2015)

[16] V. Vykhrushch, L. Romanyshyna, O. Pehota, R. Kravets, I. Shorobura, European Journal of Educational Research 9, 67-78 (2020)

[17] K. Tang, C. Chan, U. Devi, Procedia - Social and Behavioral Sciences 205, 128-133 (2015)

[18] L. Budevici Puiu, Revista Romaneasca pentru Educatie Multidimensionala 12, 350 (2020)

[19] L. Tudor, Procedia - Social and Behavioral Sciences 187, 459-463 (2015)

[20] O. Yankovych, V. Chaika, I. Yashchuk, K. Binytska, A. Kokel, O. Pysarchuk, N. Ratushniak, Espacios 40, 22-38 (2019)

[21] K. Vangrieken, F. Dochy, E. Raes, E. Kyndt, Frontline Learning Research 1, 86-98 (2013)

[22] K. Vangrieken, F. Dochy, E. Raes, European Journal of Psychology of Education 31, 275-298 (2016)

[23] European Commission, Key competences for lifelong learning (2019), https://tinyurl.com/ wrkxf9xs

[24] H. Tereshchuk, I. Kuzma, O. Yankovych, H. Falfushynska, CEUR Workshop Proceedings 2433, 145 (2019)

[25] O. Yankovych, Development of educational technologies at primary schools of Ukraine (1959-2018) (Vector, 2021)

[26] C. Peterson, S. Maier, M. Seligman, Learned helplessness: a theory for the age of personal control (Oxford University Press, 1993) 